\title{
A pilot study evaluation of student reflective thinking in a doctor of nursing practice program
}

\author{
J ulie A. Meek ${ }^{1}$, Mary E. Riner ${ }^{1}$, Daniel Pesut ${ }^{2}$, Debra Runshe ${ }^{1}$, Eman Allam ${ }^{1}$ \\ 1. Indiana University-Purdue University, Indianapolis (IUPUI), USA. 2. University of Minnesota, Minneapolis, USA.
}

Correspondence: Julie A. Meek. Address: Indiana University School of Nursing, 1111 Middle Drive, Indianapolis, IN 46202, USA. Email: juameek@iupui.edu

Received: September 30, 2012

Accepted: November 8, 2012

Online Published: January 23, 2013

DOI : $10.5430 /$ jnep.v3n8p82

URL: http://dx.doi.org/10.5430/jnep.v3n8p82

\section{Abstract}

Background: The purpose of this pilot study was to describe and explain how faculty operationalized, implemented and evaluated progression in reflective thinking as a key student transformational learning outcome in a newly created doctor of nursing practice (DNP) program.

Methods: In this pilot study, study participants (N=7) were full-time DNP students, with six having a nurse practitioner background. The key concepts of reflective thinking and transformational learning were operationalized through the use of a structured learning ePortfolio and a Reflective Writing Assignment that students completed at both mid- and end-ofprogram. Faculty gave students feedback using a Reflective Thinking Rubric. To measure progression in students' reflective thinking, a paired samples $t$-test was conducted to compare faculty ratings of students' Reflective Writing Assignments using the rubric from mid- to end-of-program.

Results: Results demonstrated a significant difference in Reflective Thinking Rubric scores from mid- $(\mathrm{M}=1.9, \mathrm{SD}=0.47)$ to end-of-program ( $\mathrm{M}=2.5, \mathrm{SD}=0.34) ; t=4.11, p=.01$, indicating a positive progression in students' transformative reflective thinking and learning.

Conclusion: Through attention to student reflective thinking and learning, the development of communities of inquiry are encouraged that are so important to the continued development of nursing knowledge and practice. Thus, structures, processes and teaching strategies that support transformational reflective thinking are important educational design components that deserve continued research.

\section{Key words}

Reflective thinking, Transformational learning, Learning ePortfolio, Scoring rubric

\section{Introduction}

The purpose of this pilot study was to describe and explain how faculty of a doctor of nursing practice (DNP) program operationalized, implemented and evaluated progression in reflective thinking as a key student transformational learning outcome in a newly created DNP program. Key concepts of reflective thinking and its importance for transformational learning are described. The use of a structured learning ePortfolio and Reflective Writing Assignment to capture the 
development and evaluation of students' reflective thinking is explained. Finally, the evaluation of students' progression in reflective thinking using a faculty-developed Reflective Thinking Rubric is reported.

\section{Key concepts of reflective thinking and transformational learning}

The development of thinking about thinking or meta-cognition is an essential skill for nurses especially as it relates to clinical reasoning and the development of clinical judgment skills and transformative learning ${ }^{[1,2]}$. Often, students do not understand that this "thinking about thinking" is really about their awareness of themselves as learners, both how they think about learning in general, and then specifically, how they can best learn. To become independent, self-directed learners, reflective thinking and transformational learning involves planning for learning, monitoring it as it occurs, and then evaluating both what has been learned and how it was learned ${ }^{[3]}$.

Mezirow ${ }^{[4]}$ contends that learning involves five interacting contexts: 1) a meaning perspective, 2) the communication process, 3) a line of action, 4) a self-concept, and 5) the external situation. Each of these interacting contexts is influenced and affected by the frames and paradigms that govern social action. Mezirow defines learning as "the process of construing and appropriating a new or revised interpretation of the meaning of an experience as a guide to awareness, feeling and action” ${ }^{[4]}$.

According to Mezirow ${ }^{[3]}$ there are three types of reflection. Content reflection is thinking about the actual experience. Process reflection is thinking how to handle the experience. And thirdly, Premise reflection involves examining long held, socially constructed assumptions, beliefs, and values about the experience or problem. "Transformative learning involves reflectively transforming the beliefs, attitudes, opinions and emotional reactions that constitute our meaning making schemes or transforming our meaning perspectives (sets of related meaning schemes)" ${ }^{[4]}$.

Creating the means to measure and evaluate content, process and premise reflection is an instructional evaluation challenge. Griffiths and Tann ${ }^{[5]}$ suggest there are at least five levels or stages of reflection. The first level of reflective practice is instinctive, immediate and called rapid reaction. The second level is more habitual and often activated on the spot and is called repair reflection. The third type of reflection (review reflection) involves time out for re-assessment and may take place over hours or days. Research reflection is systematic, sharply focused and takes place over weeks or months. Reformulation reflection is abstract, rigorous, clearly formulated and takes place over weeks, months or years. Advanced practice doctoral prepared nurses need to embrace rapid, repair, review, research and reformulation reflection. Such reflection supports the ability to self-assess, an awareness of how one learns and provides a foundation for creating life-long learning communities so important to the construction of new nursing knowledge that informs practice improvement. Once again, creating the structure, process and outcomes associated with such reflection is an evaluation challenge. Kolb's experiential learning theory suggests all learning cycles through four phases: 1) concrete experience 2) reflective observation, 3) abstract conceptualization and 4) active experimentation ${ }^{[6]}$. Providing students opportunities to cycle through these four phases of experiential learning supports reflection and contributes to transformational learning outcomes.

How advanced practice nurses prepared at the doctoral level negotiate different frames of meaning and types of reflection as they plan, execute and care for patients is a function of how well they are able to reflect in and on their actions ${ }^{[7]}$. Reflective capacity and the framing of meaning are influenced as people become aware of their "thinking about thinking" and how reflection and study of relationships between and among tacit and explicit knowledge influences and affects individual and collective ways of being, learning and doing in work based contexts ${ }^{[8]}$. Johns ${ }^{[9,10]}$ has championed the use of reflection to develop clinical skills and caring attitudes among nurses. Through attention to individual and collective reflection, action and transformative learning supports the development of communities of inquiry and practice. Thus, structures, processes and outcomes related to reflection are important educational outcomes. Ideas about reflection and ways and means to stimulate students to reflect upon their learning are valuable and important and can be transformative for students. 
Given the theories and models of reflection noted above, the challenge continues to be how best to document, measure, and evaluate the development of a students' reflection skills and abilities over time. Although there is general agreement that reflective thinking is an important student transformational learning outcome, there is much to be learned about the impact of intentional ePortfolio scaffolding and reflective thinking assignments with faculty feedback on transformative student learning. Cambridge ${ }^{[11]}$ notes that "in recent years there has been a great deal of strong research on its [eportfolio use] outcomes" and that "a wide range of disciplines and professions have documented and analyzed the use of eportfolios for supporting learning and assessment in their domains." However, Cambridge also contends that much of this research is still unclear. In an effort to clarify the connection between reflective thinking and transformational learning, faculty piloted a learning ePortfolio and a Reflective Writing Assignment as a means of structuring and documenting the process and outcomes of students' achievements in regard to reflection as a means of transformational learning.

\section{Learning ePortfolios: A structure to support reflective thinking}

With regard to learning portfolios, Zubizaretta ${ }^{[12,13]}$ describes one of the primary features: "to improve student learning by providing a structure for students to reflect systematically over time on the learning process and to develop the aptitudes, skills and habits that come from critical reflection”. Jennifer Moon ${ }^{[14]}$ describes the importance of a curriculum that supports the reflective process. Our DNP faculty agreed with Rickards and Guilbault that ${ }^{[15]}$ "Digital technology has enabled new ways of using tools like portfolios to scaffold reflective activities-by storing and making accessible multiple artifacts of student performance and records and by structuring a context for analysis and interpretation” ${ }^{[15]}$. The DNP program faculty wanted the students to make these connections between what they were learning in their coursework and what they were experiencing in clinical practice. The ePortfolio suite of tools allows these connections to be more visible to students through a matrix format that crosswalks program outcomes with course competencies and student artifacts (assignments).

The ePortfolio enables students and faculty to collect and select artifacts that provide evidence that attest to the achievement of their learning and successful mastery of course competencies and program outcomes while promoting the process of reflection and deep thinking leading to transformational learning. These program-level outcomes are built upon the principles of graduate and professional learning and nursing graduate program accreditation standards. The ePortfolio experience guides students through the process of reflection, synthesis and integration which are the hallmarks of learning. The ePortfolio also allows assessment of critical thinking, communication and problem solving which can be difficult to assess by traditional assessment methods ${ }^{[16]}$. The increased use of ePortfolios reflects a shift to a constructivist, studentcentered learning approach which relies on the students to take responsibility for and documentation of their learning ${ }^{[16]}$.

The ePortfolio process gives the students an opportunity to assess their intellectual progress, growth and development throughout the program. The students reflect on their own learning, and are prompted to explain why and how their program artifacts represent significant learning ${ }^{[17]}$. The artifacts relate to the course competencies, which align to the DNP program objectives, which, in turn, align to the American Association of Colleges of Nursing's (AACN) DNP Essentials standards ${ }^{[18]}$. Such intentional alignment from the course competencies through to the AACN standards establishes a relationship between coursework and the national intention of the DNP. Students are able to identify with the goals of the DNP program while gaining an appreciation of their own accomplishments during the process.

\section{Reflective writing assignment: A process that supports reflective thinking}

Both at the mid-point and at the end of their DNP program, students are asked to write a Reflective Writing Assignment. DNP faculty and two DNP student volunteers developed a protocol for the assignment that contains eight specific questions, that served as reflective prompts, that students used to develop their response. The eight questions were:

1) What concepts, theories, models, tools, techniques, and resources did you find most valuable?

2) How might you use this information? 
3) Why is the information important?

4) How will the knowledge improve your effectiveness?

5) How does the knowledge and information help you understand the interdependence of system dynamics, in terms of context, relationships and trends?

6) Why care about the knowledge, how does it help you clarify values and manage professional purpose?

7) How does the knowledge gained advance your achievement of program outcomes and support your mastery of the essentials for doctoral preparation as an advanced practice nurse?

8) What other thoughts reflections, or significant learning have influenced your personal and or professional development this semester?

Students become motivated and engaged as they think across and beyond their coursework to complete these Reflective Writing Assignments and realize the relevance of the course assignments to their learning and to the completion of DNP program outcomes ${ }^{[19,20]}$. Through the Reflective Writing Assignments, the students are encouraged to self-evaluate their learning and receive feedback from faculty as well about the degree to which their writing reflects a metacognitive awareness of themselves as learners ${ }^{[19,20]}$. Their self-reflection appraises the 'how and why' learning has occurred and how it fits into the larger framework of their overall development ${ }^{[13]}$.

\section{Reflective thinking rubric: Feedback mechanisms that support reflective thinking}

The final task for faculty was to select a scoring tool to evaluate the Reflective Writing Assignments. Faculty chose and adapted the Development in Reflective Thinking Rubric that had been used at the university since 2005 (see Table 1). The rubric was derived from a model of Developmental Perspectives on Reflective Thinking created by Alverno College in $2004{ }^{[21]}$. Faculty chose this rubric because it uses three primary criteria to assess the student's development of reflective thinking: the ability to self-assess, their awareness of how one learns, and the development of lifelong learning skills. Each criterion uses an anchored scale range of 1-3. The DNP program faculty made minor revisions to this rubric, emphasizing the wording and eliminating the numerical score to: Developing (1), Accomplished (2), and Proficient (3).

\section{Study purpose}

Although there is general agreement that reflective thinking is an important student transformational learning outcome, there is much to be learned about the impact of intentional ePortfolio scaffolding and reflective thinking assignments with faculty feedback on transformative student learning. Therefore, the purpose of this observational pilot study was to determine the impact of the ePortfolio matrix and Reflective Writing Assignment on student reflective thinking from midto end-of program as evidenced by faculty ratings using the Reflective Thinking Rubric.

\section{Participants and methods}

The key research question addressed whether there was a statistically significant difference in students' reflective thinking as evidenced by faculty ratings using the Reflective Thinking Rubric scores at the (a) individual item, (b) sub-scale, and (c) total scale levels between the mid- and end-of-program Reflective Writing Assignments.

The study purpose, methods, and procedures were submitted to the university's institutional review board for approval. Since all data for this observational study was de-identified and dummy coded to permit matching of each student's midto end-of-program reflective assignments' scoring, the university approved the pilot as an exempt study. The final sample included scoring for seven DNP students with three faculty ratings per student (thus 21 total ratings at both the mid- and 
end-of-program). One student's final reflective writing assignment was not able to be retrieved for scoring, so the student's mid-program scores were eliminated from the analysis. Sample characteristics included DNP students ( $\mathrm{N}=7$ ) who were all full-time students, all female, one African \& six Caucasian ethnic mix, and one student with a nursing administration and six students with nurse practitioner backgrounds.

Table 1. Reflective Thinking Rubric

\begin{tabular}{|c|c|c|c|}
\hline Areas of Reflection & Developing & Accomplished & Proficient \\
\hline \multicolumn{4}{|l|}{ Ability to self-assess } \\
\hline Observing own performance & $\begin{array}{l}\text { Global judgments without evidence; } \\
\text { sees performance same as assignment } \\
\text { (did what was told) }\end{array}$ & $\begin{array}{l}\text { Applies disciplinary constructs } \\
\text { Demonstrates deeper } \\
\text { understanding of concept }\end{array}$ & $\begin{array}{l}\text { Observes intentional changes as a } \\
\text { basis for higher learning }\end{array}$ \\
\hline Using feedback and evidence & $\begin{array}{l}\text { Repeats judgments of evaluators } \\
\text { Sees feedback as affirmation and } \\
\text { evidence }\end{array}$ & $\begin{array}{l}\text { Uses feedback to expand } \\
\text { understanding }\end{array}$ & $\begin{array}{l}\text { Probes own work and } \\
\text { understanding }\end{array}$ \\
\hline $\begin{array}{l}\text { Finding and analyzing } \\
\text { patterns }\end{array}$ & Narrates process (did this; did that) & $\begin{array}{l}\text { Recognizes connections, links, } \\
\text { and relationships, such as cause } \\
\text { and effect }\end{array}$ & $\begin{array}{l}\text { Uses multiple and } \\
\text { interdisciplinary frameworks to } \\
\text { understand }\end{array}$ \\
\hline Making judgments & Observes rather than infers & $\begin{array}{l}\text { Makes inferences (relates } \\
\text { judgments to evidence) }\end{array}$ & $\begin{array}{l}\text { Makes connections, applications, } \\
\text { and uses to move forward }\end{array}$ \\
\hline \multicolumn{4}{|l|}{ Awareness of how one learns } \\
\hline Concepts and misconceptions & $\begin{array}{l}\text { Limits concept development to the } \\
\text { terms given in the assignment } \\
\text { Sees feedback as external and not } \\
\text { subject to analysis }\end{array}$ & $\begin{array}{l}\text { Sees feedback as a means to } \\
\text { understanding links between } \\
\text { current and future performance }\end{array}$ & $\begin{array}{l}\text { Integrates feedback and past } \\
\text { performance to construct future } \\
\text { learning plans }\end{array}$ \\
\hline Knowledge construction & $\begin{array}{l}\text { Sees knowledge construction only } \\
\text { within terms of the assignment }\end{array}$ & $\begin{array}{l}\text { Notes changes in own patterns of } \\
\text { performance; sees knowledge } \\
\text { construction as integrating known } \\
\text { and new knowledge }\end{array}$ & $\begin{array}{l}\text { Uses growing awareness of } \\
\text { knowledge structures to envision } \\
\text { future learning }\end{array}$ \\
\hline Meta-cognition & $\begin{array}{l}\text { Employs personal theories largely } \\
\text { without explanation or analysis }\end{array}$ & $\begin{array}{l}\text { Applies theories or broader } \\
\text { frameworks to discussion of } \\
\text { learning }\end{array}$ & $\begin{array}{l}\text { Understands own performance as } \\
\text { a learner and transfers learning } \\
\text { strategies to multiple contexts }\end{array}$ \\
\hline \multicolumn{4}{|c|}{ Developing lifelong learning skills } \\
\hline $\begin{array}{l}\text { Developing identity as a } \\
\text { learner }\end{array}$ & $\begin{array}{l}\text { Confuses performance and feedback } \\
\text { with identity as a learner }\end{array}$ & $\begin{array}{l}\text { Self-identifies as a learner, } \\
\text { constructing meaning within } \\
\text { experience, now and in the future }\end{array}$ & $\begin{array}{l}\text { Sees own identity as a learner, } \\
\text { employing internalized } \\
\text { construction of effectiveness }\end{array}$ \\
\hline $\begin{array}{l}\text { Transferring learning to other } \\
\text { contexts }\end{array}$ & $\begin{array}{l}\text { Uses generalized notions of success or } \\
\text { effectiveness as basis for reflection }\end{array}$ & $\begin{array}{l}\text { Questions personal assumptions } \\
\text { and recognizes multiple } \\
\text { perspectives }\end{array}$ & $\begin{array}{l}\text { Questions assumptions to } \\
\text { construct intellectual } \\
\text { commitments, aware of multiple } \\
\text { perspectives }\end{array}$ \\
\hline $\begin{array}{l}\text { Understands learning as a } \\
\text { lifelong process }\end{array}$ & $\begin{array}{l}\text { Global self-evaluations minimize } \\
\text { connections between performance and } \\
\text { reflecting on performance }\end{array}$ & $\begin{array}{l}\text { Identifies challenges, } \\
\text { demonstrating positive attitude } \\
\text { and confidence, using } \\
\text { self-assessment as a basis to } \\
\text { improve }\end{array}$ & $\begin{array}{l}\text { Situates personal narrative in } \\
\text { larger intellectual/professional } \\
\text { frameworks, transferring learning } \\
\text { to new situations }\end{array}$ \\
\hline
\end{tabular}

Note. Adapted from a model of “Developmental Perspectives on Reflective thinking,” Alverno College 2004; Copyright Sharon J. Hamilton 2005, Mary E. Riner 2010.

Faculty were trained on the use of the rubric using a sample student reflective assignment and faculty members were given a comparison of their ratings with other faculty ratings with discussion thereafter to assure that faculty understood the 
rubric. Once faculty training was complete, three faculty raters scored each paper including each student's primary faculty advisor, their core course faculty and then a member of the graduate faculty so that each student had the benefit of faculty feedback and perspectives at different points in time over the course of the students' program. The rating process resulted in a total of 21 score ratings ( 7 students $\times 3$ raters each) for each rubric item at both the mid-point and then again at the end-of-program evaluation.

At the time of the mid-program ratings, inter-class correlations (ICC) were checked to determine the level of scoring agreement across faculty raters. ICC values are estimates of reliability, and, as such, may be interpreted in much the same way as Cronbach's alpha, with modest levels in the .4-.5 range, acceptable values in the .6-.7 range and good values above .8. The range of ICC's at the rubric item level ranged from .12-.55 with five of the ten items in the modest range. Faculty were made aware of these ratings prior to the end-of-program evaluations and faculty most familiar with the rubric were used to rate the students' end-of program reflective assignments.

Descriptive statistics were first examined to identify missing or out-of range values with no missing or outlier values found. The mean and standard deviation were calculated for (a) each of the individual rubric items, (b) the sub-scores for each of the three categories of reflection (ability to self-assess, awareness of how one learns, developing life-long learning skills), and (c) the total rubric score. Paired t-tests were then performed between mid- and end of program scores using Microsoft Excel (Microsoft Corporation, Redmond, WA).

\section{Results}

Figures $1 \& 2$ show boxplot descriptive results at the item, sub-score and total rubric score levels along with the degree of change from mid- to end-of-program scores. Paired $t$ test results demonstrate that students' development of reflective thinking improved significantly from mid- to end-of program. Table 2 displays the paired $t$ test results as well as the means, standard deviations, and $p$ values for all of the rubric items, sub-scores and total scores at mid and end of program. All of the individual rubric items (except for "understanding learning as a lifelong process") showed statistically significant differences from mid- to end-of- program scores. As Table 2 describes, the greatest improvements were for "awareness of how one learns concepts and misconceptions" $(p=0.00)$, the "ability to self-assess using feedback and evidence", and "finding and analyzing patterns" ( $p=0.01)$, "awareness of how one learns using metacognition" $(p=0.01)$, and "developing lifelong learning skills through transferring learning to other context" $(p=0.01)$. Significant differences ( $p=0.01$ ) also existed when sub-scores for each of the three rubric categories were compared to evaluate the "ability to self-assess", "awareness of how one learns", and "developing lifelong learning skills”. In addition, the overall rubric scale scores were also significantly different from mid- to end-of-program $(\mathrm{M}=0.6, \mathrm{SD}=0.4, p=0.01)$.

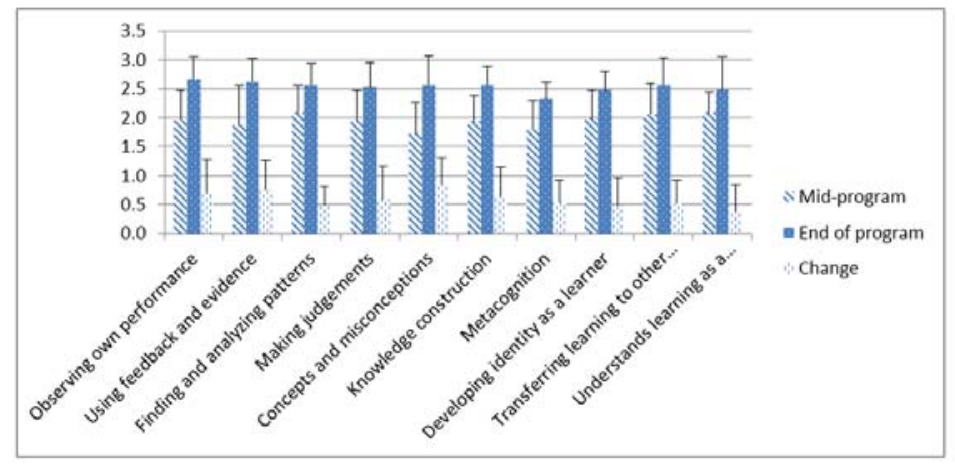

Figure 1. Reflective Thinking Rubric items at mid- and end of program and levels of change. 


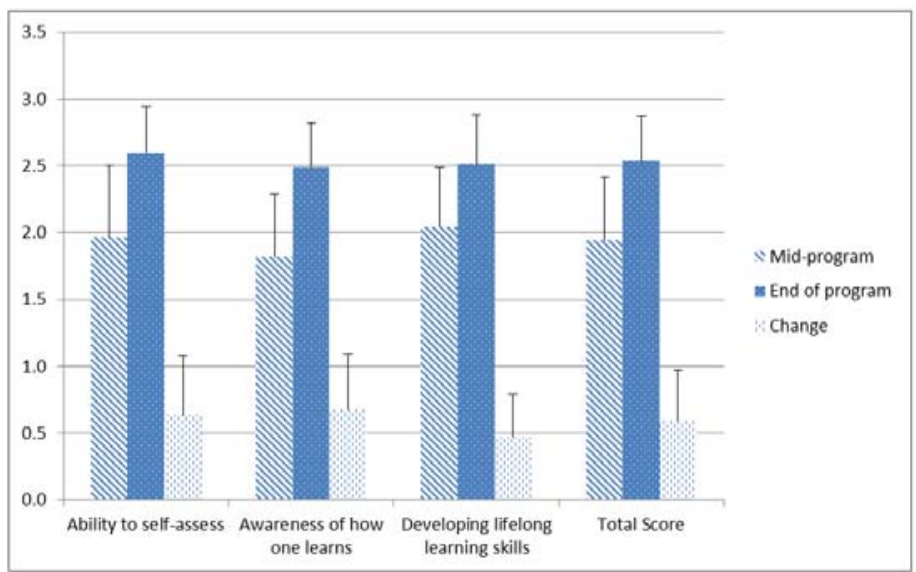

Figure 2. Reflective Thinking Rubric sub-scores plus the total score at mid- and end of program and levels of change.

Table 2. Paired t test results between mid-program and end of program reflective thinking scores

\begin{tabular}{|c|c|c|c|c|c|c|c|c|}
\hline \multirow[t]{2}{*}{ Sessions } & \multicolumn{2}{|c|}{ Mid-program } & \multicolumn{2}{|c|}{ End of program } & \multicolumn{2}{|c|}{$\begin{array}{l}\text { Score Difference } \\
\text { (end-mid) }\end{array}$} & \multirow[t]{2}{*}{$t$} & \multirow[t]{2}{*}{$p$-value } \\
\hline & Mean & SD & Mean & SD & Mean & SD & & \\
\hline Ability to Self-Assess & 2.0 & 0.54 & 2.6 & 0.35 & 0.6 & 0.4 & 3.82 & 0.01* \\
\hline $\begin{array}{l}\text { 1) Observing own } \\
\text { performance }\end{array}$ & 2.0 & 0.52 & 2.7 & 0.38 & 0.7 & 0.6 & 3.28 & $0.02 *$ \\
\hline $\begin{array}{l}\text { 2) Using feedback and } \\
\text { evidence }\end{array}$ & 1.9 & 0.70 & 2.6 & 0.40 & 0.8 & 0.5 & 3.97 & $0.01 *$ \\
\hline $\begin{array}{l}\text { 3) Finding and analyzing } \\
\text { patterns }\end{array}$ & 2.1 & 0.48 & 2.6 & 0.37 & 0.5 & 0.3 & 3.98 & $0.01 *$ \\
\hline 4) Making judgments & 1.9 & 0.55 & 2.5 & 0.42 & 0.6 & 0.6 & 2.69 & $0.04 *$ \\
\hline $\begin{array}{l}\text { Awareness of How One } \\
\text { Learns }\end{array}$ & 1.8 & 0.47 & 2.5 & 0.33 & 0.7 & 0.4 & 4.26 & $0.01 *$ \\
\hline $\begin{array}{l}\text { 5) Concepts and } \\
\text { misconceptions }\end{array}$ & 1.7 & 0.53 & 2.6 & 0.50 & 0.8 & 0.5 & 4.84 & $0.00 *$ \\
\hline 6) Knowledge construction & 1.9 & 0.43 & 2.6 & 0.32 & 0.6 & 0.5 & 3.27 & $0.02 *$ \\
\hline 7) Metacognition & 1.8 & 0.50 & 2.3 & 0.27 & 0.5 & 0.4 & 3.78 & $0.01 *$ \\
\hline $\begin{array}{l}\text { Developing Lifelong } \\
\text { Learning Skills }\end{array}$ & 2.0 & 0.44 & 2.5 & 0.37 & 0.5 & 0.3 & 3.83 & $0.01 *$ \\
\hline $\begin{array}{l}\text { 8) Developing identity as a } \\
\text { learner }\end{array}$ & 2.0 & 0.50 & 2.5 & 0.33 & 0.5 & 0.5 & 2.73 & $0.03 *$ \\
\hline $\begin{array}{l}\text { 9) Transferring learning to } \\
\text { other contexts }\end{array}$ & 2.1 & 0.53 & 2.6 & 0.46 & 0.5 & 0.4 & 3.39 & $0.01 *$ \\
\hline $\begin{array}{l}\text { 10) Understands learning as a } \\
\text { lifelong process }\end{array}$ & 2.1 & 0.37 & 2.5 & 0.57 & 0.4 & 0.5 & 2.26 & 0.06 \\
\hline Total rubric & 1.9 & 0.47 & 2.5 & 0.34 & 0.6 & 0.4 & 4.11 & $0.01 *$ \\
\hline
\end{tabular}

* Significant at $\mathrm{p}<0.05$

\section{Discussion}

Reflective thinking, like other important facets of professional practice, has both observable and unobservable elements ${ }^{[5]}$. This pilot study paper has described our initial endeavors to develop, organize, and evaluate those observable elements. 
We do not claim to have captured all that is important about reflective thinking —indeed we understand the limitations of our thinking thus far. It is useful to remember that our aim has always been to strengthen our students' ability to think deeply about their practice and about themselves as advanced practice nurses. Not coincidentally, we believe we also have become more reflective, as nurse faculty engaged in teaching the next generation of leaders and clinicians.

Although it's clear that observable and statistically significant progression in students' reflective thinking resulted from our efforts, faculty continues to think about ways to improve the educational components of the process. The ICC analysis revealed several opportunities for increasing clarity and agreement about the use of the scoring rubric. First, agreement across raters was weak to moderate, suggesting that faculty had varying levels of understanding about the rubric items and the scoring categories. One possible solution is to anchor each of the three scoring levels within each rubric item with student writing samples that exemplify attainment of that level. Also, now that the pressure of implementing the first year of a new program is past, we (faculty and students) have begun to revise the items and to re-train ourselves in scoring the reflections.

Students reported that the Reflective Writing Assignment questions were somewhat redundant so efforts are underway to refine the prompts for the next round. In an excellent article about ways to stimulate metacognition, Tanner ${ }^{[22]}$ advises two prompting strategies called "The Muddiest Point" and "retrospective postassessments". "The Muddiest Point" strategy encourages students to reflect upon what is still most confusing about what they're learning and helps students appreciate that working their way through confusion is an important step in the path toward transformational learning. The "retrospective postassessment" strategy pushes students to examine conceptual change by reflecting upon how they thought about a topic before compared to how they are thinking about the topic presently.

Also, students have advised faculty to minimize additional course-specific reflection, so students continue to view the mid- and end-of-program Reflective Writing Assignment as a special time to think broadly about their coursework to-date and how their work has affected their transformational learning paths. Students have encouraged faculty to consider more judicious use of course-related reflective activity to preserve the special place that their mid- and end-of-program Reflective Writing Assignments have in their programs of study.

Part of this discussion includes consideration of who should do the ratings-faculty who teach the DNP courses, faculty advisors of DNP students, agency mentors, or graduate faculty who have no involvement with the DNP program? Overall, we are learning what we want this process to be, as well as what we don't want it to be-it is clearly a work in progress. We need to account for the very specific ways we score reflection, as well as developing our abilities to assess the gestalt of reflective thinking. Individual faculty has tendencies in one paradigm or the other, but we have to operate in both worlds. That's what makes the process messy and also interesting.

It is important to remember that this reflective writing assignment and the attendant scoring is but one opportunity and one way to assess reflection in our program, and our intention is to create a context within which transformational learning can emerge. Qualitatively, our students' responses to this exercise, along with their other coursework, indicate that our intention is being realized. One of the study DNP students described it this way in her mid-program reflection: "I have seen purpose (and so has my boss) for what I've been learning more than ever this week. We are finalizing our "Meaningful Use” work and my project work and everything leading up to it, has made us perfectly compliant! Also, as we look ahead, the variety of things I've learned in policy class or other readings has helped me guide some of the planning and decisions we need to make to be ready for the accountable care organization model and Stage 2 of Meaningful Use requirements. I am viewed as the knowledge leader for these things and (my boss) is deferring to me. Although the informatics specifics are becoming my expertise rather than "leadership", I have also seen how important it is to lead the way to enhance and encourage adoption of innovation as we move toward more changes all of the time." What is illustrated by this quote is that this student is certainly gaining confidence due to the successful accomplishment of her practice gaining "meaningful use" 
designation for their electronic health record system. She is beginning to embrace herself as a practice leader and demonstrates that she can now see how important her leadership is in the context of all the changes her practice is facing.

Another one of the study DNP students in her final reflection upon her transformative learning commented: "Writing this final reflection paper is bittersweet. I am amazed by the knowledge, skills, and abilities that I have mastered over the last three years. When I began to take the pre-requisite courses of Statistics and Introduction to Nursing Informatics, I had basic Word skills and a very narrow focus, or "street level view", of patient care and work place issues. As I progressed in the coursework, I slowly and consistently began to see the same issues through a different lens. I gradually began to see issues from a different perspective. Three years later, I see issues from a "satellite view" as I embrace Complexity Science, System's Theory and Rogers' Diffusion of Innovation Theory. I have learned that the whole is greater than the sum of the parts. I understand that many collective minds are better than one mind working to solve problems alone.”

Another student commented on her growth as a result of the reflection work, "The DNP program was personally demanding but promoted growth through a continual process of reflection and self-assessment of values, activities and priorities. The value clarification process promotes clarity regarding an individual's personal and professional values that form the foundation for their thoughts and actions in relation to policy and politics.”

There are clear limitations to this pilot study. This pilot sample was small, and the lack of adequate time for reviewing the process and providing practice for faculty raters may well have impacted the level of inter-rater agreement. However, we believe the study design is sound, and that future work can easily address the limitations of this first attempt. In addition, we believe the process we have developed to assess the observable elements of reflective thinking, with appropriate revisions and training, will serve our students well into the future.

\section{Conclusion}

The purpose of this paper was to describe and discuss how core faculty of a DNP program operationalized, implemented and evaluated reflective thinking as a key transformational student learning outcome in a newly created DNP curriculum. The key concepts of reflection and its importance for transformational learning were operationalized through the use of a structured learning ePortfolio and a Reflective Writing Assignment process with faculty feedback using a Reflective Thinking Rubric. The educational process and writing assignments were successful in generating the desired student learning outcome as demonstrated by statistically significant differences between the mid- and end-of-program Reflective Thinking Rubric scores which reveal the strength of our reflective thinking pedagogy.

Faculty remains committed to the encouragement of reflective thinking among students as important to transformational learning for doctoral prepared advanced practice nurses. Through attention to individual and collective reflection at both the student and faculty levels, action and transformative learning supports the development of communities of inquiry and practice. Thus, structures, processes and outcomes that support reflection as a key component of transformational learning are important educational outcomes that deserve continued research.

\section{Acknowledgements}

The authors wish to acknowledge the Center for Teaching and Learning and the ePortfolio Initiative, IUPUI, for their invaluable assistance with the design and development of the e-Portfolio and reflective process for the Indiana University School of Nursing DNP program. The authors also wish to thank Dr. Michael Weaver, Professor, IU School of Nursing, for his statistical advice and assistance." 


\section{References}

[1] Kuiper R and Pesut D. Promoting cognitive and metacognitive reflective thinking skills in nursing practice: Self-regulated learning theory. Journal of Advanced Nursing. 2004; 45 (4): 381-391. PMid:14756832

http://dx.doi.org/10.1046/j.1365-2648.2003.02921.x

[2] Pesut D. Reflective clinical reasoning the development of practical intelligence as a source of power. Chapter 7 in Linda Haynes, Howard Butcher and Teresa Boese: Nursing in Contemporary Society: Issues, Trends, and transitions to practice. NJ: Prentice Hall, 2004.

[3] Weimer, M. Teaching metacognition to improve student learning, 2012. Available from:

http://www.facultyfocus.com/articles/teaching-professor-blog/teaching-metacognition-to-improve-student-learning/?utm_source =cheetah\&utm_medium=email\&utm_campaign=2012.10.31\%20-\%20Faculty\%20Focus\%20TP\%20Blog\&http://www.lifescied. org/content/11/2/113.full.pdf+htm.

[4] Mezirow J. Transformational dimensions of adult learning, San Francisco: Jossey-Bass, 1991.

[5] Griffiths M and Tann S. Ripples in the reflection. In P. Loma, Ed. BERA Dialogues. 1991: 82-101.

[6] Kolb D. Experiential learning. Prentice-Hall, New Jersey, 1984.

[7] Schön D. The Reflective Practitioner. How professionals think in action, London: Temple Smith, 1983.

[8] Raelin J. A model of work-based learning. Organization Science. 1997; 8: 563-578. http://dx.doi.org/10.1287/orsc.8.6.563

[9] Johns C. Becoming a reflective practitioner. London, England, Blackwell Science, 2000.

[10] Johns C. Becoming a reflective practitioner. London, England, Blackwell Science, 2009.

[11] Cambridge D. E-Portfolios for lifelong learning and assessment, (3rd Ed). Hoboken, NJ, USA: Jossey-Bass, 2010.

[12] Zubizarreta J. The learning portfolio. Bolton, MA: Anker Publishing, 2004. PMid:15465152

[13] Zubizarreta, J. The learning portfolio: Reflective practice for improving student learning, (2nd Ed). San Francisco, CA: Jossey-Bass, 2009.

[14] Moon J. Reflection in learning and professional development. London: Kogan Page, 1999.

[15] Rickards WH and Guilbault. Studying student reflection in an electronic portfolio environment: An inquiry in the context of practice. In D. Cambridge, B. Cambridge, \& K. Yancy (Eds.) Electronic portfolios 2.0: Emergent research on implementation and impact. Sterling, VA: Stylus Publishing LLC, 2009.

[16] Robertson JF, Rossetti J, Peters B, Coyer S, Koren ME, Hertz J, and Elder S. Portfolio assessment: One school of nursing's experience. In L. Caputi (Ed.), Teaching Nursing: The Art \& Science, Volume 1 (2nd Ed.). Glen Ellyn, IL: College of DuPage Press, 2010.

[17] Burrell S, Miners L, Nantz K, and Torosyan R. Getting started with Portfolios: A vision for implementing reflection to enhance student learning. In J. Zubizareeta (Ed.) The Learning Portfolio: Reflective Practice for Improving Student Learning (2nd Ed.). San Francisco, CA: Jossey-Bass, 2009.

[18] American Association of Colleges of Nursing. The essentials of doctoral education for advanced nursing practice, 2006. Available from: http://www.aacn.nche.edu/publications/position/DNPEssentials.pdf.

[19] Cunningham AC. Encouraging a reflective disposition: Scaffolding critical thought through portfolio development. In J. Zubizareeta (Ed.) The Learning Portfolio: Reflective Practice for Improving Student Learning (2nd Ed.). San Francisco, CA: Jossey-Bass, 2009.

[20] Wright A and Hartley MH. Upon further review: A second look at the student learning portfolio. In J. Zubizareeta (Ed.) The Learning Portfolio: Reflective Practice for Improving Student Learning (2nd Ed.). San Francisco, CA: Jossey-Bass, 2009.

[21] Hamilton S and Kahn S. Demonstrating intellectual growth and development: The IUPUI ePort. In D Cambridge, B Cambridge \& K Yancy (Eds.), Electronic portfolios 2.0: Emergent research on implementation and impact. Sterling, VA: Stylus Publishing LLC, 2009.

[22] Tanner, K. D. Promoting student metacognition. Cell Biology Education—Life Sciences Education. 2012; 11: 113-120. 